Proceedings

\title{
Ethanol Extract of Cassia sieberiana Leaves Ameliorates Deviances Associated with Benign Prostatic Hyperplasia in Rats ${ }^{\dagger}$
}

\author{
Ekeyi Yusuf, Uchendu Nene O.* and Anaduaka Emeka G. \\ Department of Biochemistry, Faculty of Biological Sciences, University of Nigeria, Nsukka, Nigeria; \\ yusufekeyi11@gmail.com (E.Y.); emeka.anaduaka@unn.edu.ng (A.E.G.) \\ * Correspondence: emeka.anaduaka@unn.edu.ng; Tel.: +234-8064212224 \\ + Presented at the 1st International e-Conference on Antioxidants in Health and Disease, 01-15 December \\ 2020; Available online: https://cahd2020.sciforum.net/.
}

Published: 30 November 2020

\begin{abstract}
This study investigates the curative response of ethanol extract of Cassia sieberiana leaves (EECSL) on testosterone-induced benign prostatic hyperplasia (BPH). Thirty rats (120-160 g) were grouped into six of five rats each. Group 1 was the normal control; groups 2-6 were induced with testosterone ( $5 \mathrm{mg} / \mathrm{kg}$ body weight) for twenty-one days following standard procedures. Group 2 serves as BPH-control, groups 3 received finasteride while 4-6 received orally 100, 300 and 500 $\mathrm{mg} / \mathrm{kg}$ of EECSL respectively for 14 days. Biochemical and BPH indices were analyzed. Oral administration of EECSL showed a decrease in prostate weight, Prostate specific antigen (PSA), testosterone and dihydrotestosterone (DHT), triacylglycerol (TAG), total cholesterol (TC), low density lipoprotein (LDL), malondialdehyde (MDA), aspartate aminotransferase (AST) alanine aminotransferase (ALT) whereas an elevation in High density lipoprotein (HDL), GSH and likewise antioxidant enzymes superoxide dismutase (SOD) and catalase (CAT) activities were recorded. The histology photomicrograph showed that EECSL restored lesions of testosterone induction in the treated groups. Our study reveals that EECSL exert potent on $\mathrm{BPH}$, hypolipidaemic and antioxidant potentials and justifies the claims by the traditional doctors in BPH management.
\end{abstract}

Keywords: benign prostatic hyperplasia; Cassia sieberiana; antioxidants; oxidative stress; prostate tissues; testosterone

\section{Introduction}

Prostate disorders are pathological disease that causes inflammation and mass enlargement of the prostatic epithelial and stromal cells which causes proliferation and death of prostate cells. Majority of the predisposing factors associated with BPH like age, genetic factors, sex hormones and metabolic syndrome are the hallmark to the development of BPH (Aakula et al., 2016). Dihydrotestosterone (DHT) combines to androgen receptors and forms complex with testosterone by the action of $5 \alpha$-reductase(s) activities which enhances protein synthesis and prostatic cell growth (Liao et al., 2012). Early signs of BPH are manifested through the narrowing of urethra excretion of urine and difficulty in complete empty of the bladder which may cause bladder inflation and hormonal inbalance (Yano et al., 2001). Standard treatment for clinically localized prostate disorders include; watchful waiting, surgical and medical therapy (Mustafa et al., 2016). Considering the importance of DHT in the manifestation of BPH, definite blockers of $5 \alpha$-reductase, such as finasteride 
The 1st International Electronic Conference on Antioxidants in Health and Disease, 1-15 December 2020

and dutasteride are the target drugs of choice for the management of BPH. Consequently, the excessive intake of these target drugs may impair low libido, ejaculation disorder and erectile dysfunction (Bullock and Andriole 2006). However, increase the use of alternative ways for the treatment and management of $\mathrm{BPH}$ is sought after. It was estimated that about $30 \%$ of men diagnosed of BPH used complementary and alternative medicine (Ejike and Ezeanyika 2011; Rafieian-Kopaei 2012; Singh 2015).

Cassia sieberiana belongs to the family Fabaceae (Leguminosae-Caesalpinioiceae). The drumstick tree is a relatively unknown African plant species regarded as weed (Singh 2017). The plant grows like many other weeds until recently when researchers' attention is being shifted to it medicinal values (Olapade et al., 2012). In Nigeria, extracts of C. sieberiana plant have been used in folklore for the treatment of tooth pain, icterus, inflammation, weakness of the bones and joints (Sam et al., 2011). The plant leaf extract has been reported to be rich in phytochemical constituents and exhibits antibacterial and anti-inflammatory activity (Donkor et al., 2013). Previous studies showed that ethanolic root extract of $C$. sieberiana had an anti parasitic effect, myorelaxant and anti-spasmodic activity (Duwiejua et al., 2007; Sy et al., 2009), anti-microbial activity against some bacteria and viruses (Sliva et al., 1997), analgesic and anti-inflammatory activity (Sy et al., 2009) and anti malarial potentials of the leaf extract has been documented (Aliyu et al., 2013). Its leaf extract decoction is used traditionally to manage $\mathrm{BPH}$ with no documentation in scholarly literature. Hence, our study aimed at investigating and to validate the potent of EECSL on testosterone-induced $\mathrm{BPH}$ in experimental animals.

\section{Materials and Methods}

\subsection{Plant Materials and Extraction Procedure}

Fresh leaves of Cassia sieberiana were sourced from Odu Ajaruwa-Eke in Dekina Local Government Area of Kogi State. The plant sample was identified by Mr. Alfred Ozioko of Bioresources Development and Conservation Programme (BDCP) Research Centre, Nsukka, Enugu State, Nigeria, with the identification number, Intercedd/162946. The leaves of C. sieberiana were washed in clean water, air dried and ground to powdered form. Six hundred grams of powdered $C$. sieberiana leaves was soaked in $1.7 \mathrm{~L}$ of absolute ethanol. The solution was filtered with Whatman No. 4 filter paper; the filtrate was concentrated to slurry using a rotary evaporator at a temperature of 40 ${ }^{\circ} \mathrm{C}$.

\subsection{Animals}

Thirty adult male Wistar rats (120-160 g) sourced from the facility of Biological Sciences Faculty, University of Nigeria, Nsukka animal house. The animals were housed at room temperature and acclimatized for 14 days with constant supply of water and commercial pellet rat feed (Standard Grower's, Grand Cereals LTD, Enugu, Nigeria). Guidelines for the care and use of animals were strictly followed in this study (Indian Council of Medical Research, 2001).

\subsection{BPH Induction}

The rats were divided into six (6) of five (5) rats each. Group 1 was not induced nor treated (normal control), group 2 was induced but not treated (Untreated control), group 3 was induced and received $1 \mathrm{mg} / \mathrm{kg}$ b.w of finansteride (standard control) while groups 4, 5, and 6 were induced and received 100, 300, and $500 \mathrm{mg} / \mathrm{kg}$ b.w of EECSL (low, mid and high dose) respectively. Experimentally developed BPH model was created in the male rats by hypodermic injection of testosterone $(5 \mathrm{mg} / \mathrm{kg}$ body weight (b.w)) for three (3) weeks as reported by Al-Trad et al., (2019), with little adjustment. The PSA levels of the rats were determined to confirm that the induction was successful. Treatment with standard drug and different doses of extract commenced on the next day which represents the first day of treatment and it continued for 14 days. The oral administration (treatment) was done once 
The 1st International Electronic Conference on Antioxidants in Health and Disease, 1-15 December 2020 per day by the use of gavages. Carboxymethyl cellulose (CMC) was used as the vehicle. The weight of the rats was recorded at the beginning of the experiment and every week for two weeks using electronic weighing balance. The bodyweight gain was estimated by the subtraction of the finalweight from the initial weight. The percentage prostate index and PSA differences were calculated by the difference in mean prostate index between the induced group without treatment minus that of the treated group multiply by 100. After treatment, the rats were deprived of food and water overnight and sacrificed. Blood samples and tissues (prostate gland, testis, and bladder) were collected for analyses. The tissues were weighed and recorded. The prostate index was estimated by dividing the prostate weight with the total bodyweight.

\subsection{Biochemical Analysis}

Serum PSA, testosterone and DHT levels were analyzed using PSA/testosterone ELISA kit (Monobind Inc. Lake Forest, CA 92630, USA) and DHT ELISA kit (ALPCO, 26-G Keewaydin Drive Salem NH 03079, USA) respectively, following the manufacturer's instructions. The concentration of serum lipid profile was determined using the following methods: cholesterol, Abell et al., (1952); triacylglycerols, Tietz (1990); high density lipoproteins, Albers et al., (1978); and low density lipoproteins, Friedewald et al., (1972). The oxidative stress markers were determined after depriving the rat food and water overnight. The prostate tissue was harvested and homogenized for the assays. Superoxide dismutase (SOD) activity was assayed following the method of Fridovich (1989). Catalase (CAT) was assayed by the method of Aebi (1983). Glutathione (GSH) level was analyzed by the method of Goldberg and Spooner (1983). Lipid peroxidation product, malondialdehyde (MDA) was determined spectrophotometrically by the method of Wallin et al., (1993). Alanine aminotransferase (ALT) and aspartate aminotransferase (AST) activities were assayed using the method of Reitman and Frankel (1957). Alkaline phosphatase activity was assayed according to the method of Babson et al., (1966).

\subsection{Tissue Histology}

The histological examination of the experimental animal prostate tissues was carried out according to the method of Drury et al., (1967). The tissues were fixed in $10 \%$ phosphate buffered formalin for about $48 \mathrm{~h}$. Subsequently, the tissues were trimmed, dehydrated in four different grades of alcohol, cleared in 3 grades of xylene and embedded in molten wax.

\subsection{Statistical Analysis}

Data were analyzed with Statistical Package for Service Solutions (SPSS, version 23) and were presented as means \pm standard deviation (SD). This was subjected to a one-way analysis of variance (ANOVA) followed by Duncan multiple tests and differences between means were considered significant when $p<0.05$.

\section{Results and Discussion}

\subsection{Body Weight Gain}

A significant increase was recorded in the final body weight of the animals in comparison to their initial weight. Subcutaneous injection of testosterone had no significant $(p>0.05)$ difference in weight gains in the untreated/treatment groups in comparison to the normal control (Table 1). Similar trend was observed by Park et al., (2017) which reported a non-significant elevation in the body weight gain of experimentally induced BPH animals compared to the normal control. This could be attributed to the differences in the initial whole body weights and unknown physiological processes that may have occurred during prostate enlargement and metabolism of administered substances. 
The 1st International Electronic Conference on Antioxidants in Health and Disease, 1-15 December 2020

Table 1. Effect of EECSL on body weight gain of the rats.

\begin{tabular}{llll}
\hline Group & Initial-Weight $(g)$ & Final-Weight $(g)$ & Weight-Gain (g) \\
\hline Normal Control & $143.41 \pm 9.66^{\mathrm{ab}}$ & $197.05 \pm 12.04^{\mathrm{ab}}$ & $52.44 \pm 4.10^{\mathrm{a}}$ \\
Untreated Control & $125.10 \pm 10.91^{\mathrm{a}}$ & $177.34 \pm 16.87^{\mathrm{a}}$ & $50.52 \pm 7.58^{\mathrm{a}}$ \\
Standard Control & $121.67 \pm 7.77^{\mathrm{a}}$ & $177.24 \pm 16.81^{\mathrm{a}}$ & $55.57 \pm 9.70^{\mathrm{a}}$ \\
Low Dose & $126.11 \pm 4.01^{\mathrm{a}}$ & $177.31 \pm 5.79^{\mathrm{a}}$ & $51.59 \pm 2.52^{\mathrm{a}}$ \\
Mid Dose & $138.06 \pm 29.11^{\mathrm{ab}}$ & $190.57 \pm 29.79 \mathrm{ab}$ & $52.52 \pm 0.94^{\mathrm{a}}$ \\
High Dose & $156.61 \pm 16.43^{\mathrm{b}}$ & $211.03 \pm 20.95^{\mathrm{b}}$ & $54.42 \pm 14.23^{\mathrm{a}}$ \\
\hline
\end{tabular}

Values are expressed as mean $\pm \mathrm{SD},(n=5)$. Values in the same column having different superscripts differ significantly $(p<0.05)$. Normal Control: Not induced, not treated; Untreated Control: testosterone induced BPH left untreated; Standard Control: testosterone induced BPH (TIB), treated with finasteride ( $1 \mathrm{mg} / \mathrm{kg}$ b.w); Low Dose: TIB treated with extract (100 mg/kg b.w); Mid Dose: TIB treated with extract (300 mg/kg b.w); High Dose: TIB treated with extract (500 mg/kg b.w).

\subsection{Effect of EECSL on Prostate Parameters}

Prostate weight was significantly high in BPH group in comparison to the normal control whereas, EECSL treated group (high dose) significantly lowered the prostate weight in comparison to the untreated control. The standard group gave $17.24 \%$ decrease in comparison to the untreated control while the EECSL administered groups displayed dose dependent $(100,300$, and $500 \mathrm{mg} / \mathrm{kg}$ ) decrease of $17.24 \%, 20.69 \%$, and $27 \%$ respectively (Table 3 ). Changes in the bladder and testes weight of the rats were observed.

The prostate index of the untreated control significantly elevated more than half in comparison to the normal control group whereas, the standard and EECSL treated groups were significantly lowered in prostate index in comparison to the non-treated control. The standard control gave $14.63 \%$ decrease in comparison to the untreated control while the EECSL administered groups gave a dose dependent $(100,200$ and $500 \mathrm{mg} / \mathrm{kg}$ ) decrease of $20.73 \%, 26.83 \%$, and $38.41 \%$ respectively.

The bladder weight was significantly high in the untreated group in comparison to the normal control whereas, the testes weight was significantly decreased in the BPH group. The oral doses of standard drug and EECSL had no effect on the weight of the testes in comparison to the untreated control. This elevated weight of prostate parameters could be attributed to the effect of exogenous hormone administered to the untreated group. Prostatic weight increase is a vital signal in BPH biomarkers (Veeresh et al., 2010). Treatment with different dose of the EECSL has demonstrated to be effective in prostatic tissues haven caused a relative decrease in prostate weight and index (PWI). Similar decline in PWI was recorded in standard control which however displayed comparably less effect compared to the plant extract. The decrease in the prostate weight in extract treated group could be ascribed to the abundance of antioxidants in the plants as reported by Mbaka et al., (2017) that effective use of plant extracts could reduce prostate weight and reverses degenerative changes in the structure of the prostate gland. The reduction in size of the prostate that occurred in the EECSL treated group (high dose) indicates that the prostate size reduction could not have been caused by spontaneous reversal of hyperplasia exogenously induced. Therefore, the extract may possess ability to inhibit growth factor that causes cell proliferation or glandular expansion as observed in prostate weight reduction.

Interestingly, Cassia sieberiana leaves extract enhanced antioxidant defence mechanism which could be attributed to its phenolics content such as flavonoids, and tannins that may result in attenuating testosterone-induced prostatic hyperplasia (Donkor et al., 2013). The antioxidant properties of the plant may explain its utilization and benefits in traditional medicine to alleviate pathological condition of the prostate. In addition, a significant elevation and decrease in bladder weight and testes weight respectively, was noticed in the untreated control in comparison to the normal control. The changes noticed in the bladder may result to an inflamed prostate gland which obstruct bladder outflow thereby causing difficulties in urination and weakens the bladder muscles (Bhavsar and Verma, 2014; Thu et al., 2017). 
The 1st International Electronic Conference on Antioxidants in Health and Disease, 1-15 December 2020

Table 2. Effect of EECSL on the weight of prostate, bladder, testes, and prostate index.

\begin{tabular}{lllll}
\hline Group & Prostate $(\mathrm{g})$ & Bladder $(\mathrm{g})$ & Testes $(\mathrm{g})$ & Prostate Index $(\mathrm{mg} / \mathrm{g})$ \\
\hline Normal Control & $0.20 \pm 0.06^{\mathrm{a}}$ & $0.05 \pm 0.01^{\mathrm{a}}$ & $2.67 \pm 0.15^{\mathrm{b}}$ & $1.07 \pm 0.34^{\mathrm{a}}$ \\
Untreated Control & $0.30 \pm 0.04^{\mathrm{b}}$ & $0.08 \pm 0.01^{\mathrm{b}}$ & $2.24 \pm 0.44^{\mathrm{a}}$ & $1.64 \pm 0.18^{\mathrm{b}}$ \\
Standard Control & $0.24 \pm 0.04^{\mathrm{ab}}$ & $0.07 \pm 0.01^{\mathrm{b}}$ & $1.89 \pm 0.44^{\mathrm{a}}$ & $1.36 \pm 0.22^{\mathrm{ab}}$ \\
Low Dose & $0.23 \pm 0.09^{\mathrm{ab}}$ & $0.07 \pm 0.00^{\mathrm{b}}$ & $2.11 \pm 0.31^{\mathrm{a}}$ & $1.27 \pm 0.44^{\mathrm{ab}}$ \\
Mid Dose & $0.23 \pm 0.04^{\mathrm{ab}}$ & $0.07 \pm 0.01^{\mathrm{b}}$ & $2.01 \pm 0.15^{\mathrm{a}}$ & $1.20 \pm 0.14^{\mathrm{a}}$ \\
High Dose & $0.21 \pm 0.02^{\mathrm{a}}$ & $0.07 \pm 0.01^{\mathrm{b}}$ & $2.00 \pm 0.20^{\mathrm{a}}$ & $1.01 \pm 0.09^{\mathrm{a}}$ \\
\hline
\end{tabular}

Values are expressed as mean $\pm \mathrm{SD},(n=5)$. Values in the same column having different superscripts differ significantly $(p<0.05)$. Normal Control: Not induced, not treated; Untreated Control: testosterone induced BPH left untreated; Standard Control: testosterone induced BPH (TIB), treated with finasteride ( $1 \mathrm{mg} / \mathrm{kg} \mathrm{b.w})$; Low Dose: TIB treated with extract (100 mg/kg b.w); Mid Dose: TIB treated with extract (300 mg/kg b.w); High Dose: TIB treated with extract (500 mg/kg b.w).

\subsection{Effect of the EECSL on Serum PSA Level}

Subcutaneous induction of testosterone significantly raised serum PSA level in untreated control in comparison to the normal control. The elevation of serum PSA level after injection with testosterone followed same trend with Afriyie et al., (2014) who recorded that DHT is phosphorylated to form PSA inside the prostatic stromal cells. This elevation of PSA values shows that testosterone injection successfully induced BPH, since PSA is secreted by the epithelial cell of the prostate gland. Thus, abnormal serum level of PSA serves as a direct indicator of prostatic disorder (Velonas et al., 2013).

The PSA level in the standard control and the EECSL treated groups was significantly $(p<0.05)$ lowered after 2 weeks of administration in comparison to the initial PSA level before treatment (Table 3). The finasteride group displayed $60.78 \%$ reduction in PSA level compared to the initial PSA whereas, the PSA level in the EECSL treated groups $(100,300$, and $500 \mathrm{mg} / \mathrm{kg}$ ) showed a dose dependent decrease of $43.68 \%, 51.45 \%$, and $57.30 \%$ respectively compared to their initial PSA levels before treatment. The PSA level of the untreated control was not significantly lowered. The administration of EECSL blocked the evolution of BPH and reversed the prostatic condition closely to normal, which was observed by significant reduction in serum PSA level. The lowered serum PSA levels of EECSL treated rats may be related to its inhibitory effect on the $5 \alpha$-reductase activity which converse testosterone to its potent form (DHT) and has high affinity for binding androgen receptor leading to BPH progression and development. Although, the peak reversal effect on serum PSA levels observed in the standard and extract treated groups was not the same as the PSA level of the normal control, the difference may be largely due to short duration of treatment. Therefore, if the treatment period was extended, a maximum effect of the extract may be revealed. The untreated control was used to monitor the reversal rate of the prostatic condition.

Table 3. Effect of EECSL on serum PSA of testosterone-induced BPH.

\begin{tabular}{lll}
\hline Group & PSA (Before Treatment) $(\mathbf{n g} / \mathbf{m L})$ & PSA (After Treatment) $(\mathbf{n g} / \mathbf{m L})$ \\
\hline Normal Control & $2.86 \pm 0.15^{\mathrm{a}}$ & $2.98 \pm 0.09^{\mathrm{a}}$ \\
Untreated Control & $8.49 \pm 0.35^{\mathrm{b}}$ & $8.12 \pm 0.21^{\mathrm{e}}$ \\
Standard Control & $8.21 \pm 0.52^{\mathrm{b} *}$ & $3.22 \pm 0.27^{\mathrm{ab}}$ \\
Low Dose & $8.15 \pm 0.36^{\mathrm{b}}$ & $4.59 \pm 0.21^{\mathrm{d}}$ \\
Mid Dose & $7.95 \pm 0.36^{\mathrm{b}}$ & $3.86 \pm 0.06^{\mathrm{c}}$ \\
High Dose & $8.15 \pm 0.26^{\mathrm{b}}$ & $3.48 \pm 0.15^{\mathrm{b}}$ \\
\hline
\end{tabular}

Values are expressed as mean $\pm \mathrm{SD},(n=5)$. Values in the same column having different superscripts differ significantly $(p<0.05)$; values in the same row having asterisk $\left(^{*}\right)$ as superscripts differ significantly $(p<0.05)$. PSA $=$ prostatic specific antigen. 
The 1st International Electronic Conference on Antioxidants in Health and Disease, 1-15 December 2020

3.4. Effect of the EECSL on Serum Testosterone and DHT Level

The subcutaneous injection of testosterone significantly elevated the serum testosterone in comparison to the normal control (Table 4). The elevated serum testosterone concentration was significantly reduced by finasteride and different doses of EECSL. The extract treated group showed a dose-dependent decrease observed at $500 \mathrm{mg} / \mathrm{kg}$ (27.30\%). Also, the untreated control group showed significant elevation in serum DHT concentration in comparison to the normal control. The EECSL administered groups were significantly lowered the serum DHT level with maximum decrease at $100 \mathrm{mg} / \mathrm{kg}$. The reduction in testosterone and DHT serum levels in the EECSL treated rats could be attributed to the EECSL activity which enhanced the decrease in the levels of circulating testosterone and DHT that could constitute risk factors for hyperplasia of prostate gland. This indicates that the EECSL improves the clearing unbound testosterone in the bloodstream and blocks its translation to active DHT by $5 \alpha$-reductase (Roehrborn et al., 2007).

Table 4. Effect of EECSL on serum testosterone and DHT levels of testosterone-induced BPH.

\begin{tabular}{lll}
\hline Group & Testosterone $(\mathrm{ng} / \mathrm{mL})$ & DHT $(\mathbf{n g} / \mathbf{m L})$ \\
\hline Normal Control & $8.58 \pm 0.95^{\mathrm{a}}$ & $2.44 \pm 0.04^{\mathrm{c}}$ \\
Untreated Control & $21.61 \pm 2.52^{\mathrm{c}}$ & $2.82 \pm 0.06^{\mathrm{d}}$ \\
Standard Control & $10.95 \pm 1.23^{\mathrm{a}}$ & $2.27 \pm 0.05^{\mathrm{abc}}$ \\
Low Dose & $20.54 \pm 0.58^{\mathrm{c}}$ & $2.15 \pm 0.19^{\mathrm{a}}$ \\
Mid Dose & $19.92 \pm 0.51^{\mathrm{c}}$ & $2.39 \pm 0.16^{\mathrm{bc}}$ \\
High Dose & $16.22 \pm 1.38^{\mathrm{b}}$ & $2.23 \pm 0.08^{\mathrm{ab}}$ \\
\hline
\end{tabular}

Values are expressed as mean $\pm \mathrm{SD},(n=4)$. Values in the same column having different superscripts differ significantly $(p<0.05)$. DHT= Dihydrotestosterone.

\subsection{Effect of EECSL on Lipid Profile}

The injection of testosterone significantly elevated serum TAG, TC, and LDL compared to normal control. The increase in serum lipid (TAG, TC, and LDL) was reduced by treatment of rats with standard drug and different doses of EECSL with a sharp reduction recorded at higher dose $(500 \mathrm{mg} / \mathrm{kg})$ of the EECSL. The increment supports the reports by Parsons et al., (2008) that hypercholesterolemia may affect the sex steroid axis and result in BPH.

Meanwhile, serum concentration of LDL was lowered $(p<0.05)$ significantly at mid and high doses in comparison to the untreated group. However, the induction of testosterone significantly lowered the serum HDL level in comparison to the normal control (Table 5). High density lipoprotein in contrast to the TAG, TC and LDL was elevated significantly in the standard and the EECSL administered groups in comparison to the untreated control. Dyslipidemia has a link to metabolic syndrome and invariable exposes one to BPH (Liu et al., 2010; Duru et al., 2015). However, treatment with different doses of EECSL attenuated the progression of BPH as observed in this study.

Table 5. Effect of EECSL on lipid profile of testosterone-induced BPH.

\begin{tabular}{lllll}
\hline Group & TAG (mmol/L) & TC (mmol/L) & HDL (mmol/L) & LDL (mmol/L) \\
\hline Normal Control & $1.34 \pm 0.05^{\mathrm{a}}$ & $4.90 \pm 0.44^{\mathrm{ab}}$ & $2.01 \pm 0.11^{\mathrm{b}}$ & $2.72 \pm 0.06^{\mathrm{b}}$ \\
Untreated Control & $1.67 \pm 0.11^{\mathrm{b}}$ & $5.30 \pm 0.36^{\mathrm{b}}$ & $1.46 \pm 0.03^{\mathrm{a}}$ & $3.50 \pm 0.34^{\mathrm{c}}$ \\
Standard Control & $1.48 \pm 0.18^{\mathrm{ab}}$ & $4.40 \pm 0.85^{\mathrm{a}}$ & $1.90 \pm 0.16^{\mathrm{b}}$ & $2.43 \pm 0.49^{\mathrm{b}}$ \\
Low Dose & $1.67 \pm 0.08^{\mathrm{b}}$ & $4.60 \pm 0.40^{\mathrm{ab}}$ & $1.53 \pm 0.17^{\mathrm{a}}$ & $2.80 \pm 0.25^{\mathrm{b}}$ \\
Mid Dose & $1.45 \pm 0.10^{\mathrm{a}}$ & $4.07 \pm 0.25^{\mathrm{a}}$ & $1.91 \pm 0.34^{\mathrm{b}}$ & $1.73 \pm 0.36^{\mathrm{a}}$ \\
High Dose & $1.33 \pm 0.10^{\mathrm{a}}$ & $4.03 \pm 0.12^{\mathrm{a}}$ & $1.92 \pm 0.17^{\mathrm{b}}$ & $1.85 \pm 0.08^{\mathrm{a}}$ \\
\hline
\end{tabular}

Values are expressed as mean $\pm \mathrm{SD},(n=4)$. Values in the same column having different superscripts differ significantly $(p<0.05)$. TAG $=$ Triacylglycerol; TC $=$ Total cholesterol; LDL $=$ Low density lipoprotein; HDL = High density lipoprotein. 
The 1st International Electronic Conference on Antioxidants in Health and Disease, 1-15 December 2020

3.6. Effect of EECSL on Oxidative Stress Markers

The activities of superoxide dismutase (SOD) and catalase (CAT) were significantly lowered whereas, glutathione reductase (GSH) showed no significant change in the untreated control compared to the normal control (Table 6). The standard and EECSL treated groups showed an improved recovery in the SOD and CAT activities compared to the untreated group with the EECSL administered groups showing a dose dependent elevation in SOD activity. Also, the induction of animals with testosterone gave a significant elevation in malondialdehyde (MDA) concentration (Table 6). Lipid peroxidation lowers antioxidant levels in BPH (Aryal et al., 2007). Elevation of MDA serves as signal to lipid peroxidation and tissue damage which is associated with the development of BPH (Aydin et al., 2006). The EECSL treated groups significantly lowered MDA at mid/high dose compared to the untreated control. The preventive action of EECSL could be attributed to its secondary metabolites (Donkor et al., 2013).

Table 6. Effect of EECSL on oxidative stress markers in testosterone-induced BPH rats.

\begin{tabular}{lllll}
\hline Group & GSH (mg/dl) & SOD (U/mg) & CAT (U/mg) & MDA (mg/mL) \\
\hline Normal Control & $2.18 \pm 0.08^{\mathrm{ab}}$ & $11.50 \pm 0.07^{\mathrm{b}}$ & $8.92 \pm 0.01^{\mathrm{c}}$ & $1.16 \pm 0.22^{\mathrm{a}}$ \\
Untreated Control & $1.83 \pm 0.11^{\mathrm{a}}$ & $10.58 \pm 0.24^{\mathrm{a}}$ & $5.37 \pm 1.08^{\mathrm{a}}$ & $1.55 \pm 0.09^{\mathrm{b}}$ \\
Standard Control & $2.32 \pm 0.08^{\mathrm{b}}$ & $11.47 \pm 0.61^{\mathrm{b}}$ & $7.74 \pm 0.53^{\mathrm{bc}}$ & $1.58 \pm 0.02^{\mathrm{b}}$ \\
Low Dose & $2.14 \pm 0.25^{\mathrm{ab}}$ & $11.40 \pm 0.01^{\mathrm{b}}$ & $6.62 \pm 0.42^{\mathrm{ab}}$ & $1.61 \pm 0.27^{\mathrm{b}}$ \\
Mid Dose & $2.19 \pm 0.30^{\mathrm{ab}}$ & $11.44 \pm 0.04^{\mathrm{b}}$ & $7.88 \pm 1.54^{\mathrm{bc}}$ & $1.27 \pm 0.06^{\mathrm{a}}$ \\
High Dose & $2.25 \pm 0.36^{\mathrm{ab}}$ & $11.54 \pm 0.05^{\mathrm{b}}$ & $7.75 \pm 0.61^{\mathrm{bc}}$ & $1.21 \pm 0.09^{\mathrm{a}}$ \\
\hline
\end{tabular}

Values are expressed as mean $\pm \mathrm{SD}(n=4)$. Values in the same column having different superscripts differ significantly $(p<0.05)$. GSH $=$ Glutathione reductase; SOD = Superoxide dismutase; $\mathrm{CAT}=$ Catalase; $\mathrm{MDA}=$ Malondialdehyde. Normal Control: Not induced, not treated; Untreated Control: testosterone induced BPH left untreated; Standard Control: testosterone induced BPH (TIB), treated with finasteride ( $1 \mathrm{mg} / \mathrm{kg}$ b.w); Low Dose: TIB treated with extract (100 mg/kg b.w); Mid Dose: TIB treated with extract (300 mg/kg b.w); High Dose: TIB treated with extract (500 mg/kg b.w).

\subsection{Effect of EECSL on Liver Marker Enzymes}

There was no significant change in the activities of the liver marker enzymes (AST, ALT) in the treatment group when compared to the untreated control (Table 7). However, ALP was significantly lowered in standard control and high dose of EECSL compared to the untreated group with the treatment groups showing dose dependent decrease. The serum activities of these markers are indicators of liver damage and there concentrations may be elevated in the blood stream (Mimae 2017). In our study, no significant increase in these markers was recorded in the administration of standard drug and EECSL in rats, indicating that the EECSL administered at a varying doses were safe.

Table 7. Effect of EECSL on liver marker enzymes.

\begin{tabular}{llll}
\hline Group & AST (U/L) & ALT (U/L) & ALP (U/L) \\
\hline Normal Control & $27.00 \pm 1.00^{\mathrm{a}}$ & $19.00 \pm 2.65^{\mathrm{a}}$ & $17.33 \pm 1.15^{\mathrm{bc}}$ \\
Untreated Control & $38.67 \pm 4.93^{\mathrm{c}}$ & $21.33 \pm 0.58^{\mathrm{b}} \mathrm{a}^{\mathrm{b}}$ & $19.00 \pm 2.00^{\mathrm{c}}$ \\
Standard Control & $28.67 \pm 5.77^{\mathrm{ab}}$ & $23.67 \pm 1.15^{\mathrm{b}}$ & $14.00 \pm 1.00^{\mathrm{a}}$ \\
Low Dose & $36.33 \pm 3.79 \mathrm{~b}^{\mathrm{c}}$ & $23.33 \pm 1.53^{\mathrm{b}}$ & $17.67 \pm 2.31^{\mathrm{bc}}$ \\
Mid Dose & $34.00 \pm 5.00 \mathrm{a}^{\mathrm{bc}}$ & $22.33 \pm 1.55^{\mathrm{b}}$ & $15.33 \pm 1.53^{\mathrm{ab}}$ \\
High Dose & $34.00 \pm 4.36^{\mathrm{abc}}$ & $21.00 \pm 0.00^{\mathrm{ab}}$ & $13.67 \pm 1.53^{\mathrm{a}}$ \\
\hline
\end{tabular}

Values are expressed as mean \pm SD $(n=4)$. Values in the same column having different superscripts differ significantly $(p<0.05)$. AST $=$ Aspartate aminotransferase; ALT = Alanine transaminase; ALP = Alkaline phosphatase. Normal Control: Not induced, not treated; Untreated Control: testosterone induced BPH left untreated; Standard Control: testosterone induced BPH (TIB), treated with 
The 1st International Electronic Conference on Antioxidants in Health and Disease, 1-15 December 2020

finasteride (1 mg/kg b.w); Low Dose: TIB treated with extract (100 mg/kg b.w); Mid Dose: TIB treated with extract (300 mg/kg b.w); High Dose: TIB treated with extract (500 mg/kg b.w).

The histo-architecture revealed that EECSL restored the damaged prostatic epithelial cells and reduced prostate size (Figure 1). The histological changes observed in Figure 1B (BPH untreated group) confirms the characteristics earlier documented by Mbaka et al., (2017) and Ikeyi et al., (2020). The mode of action may be linked to the binding of DHT to androgen receptors which promotes protein synthesis and prostatic cell growth.
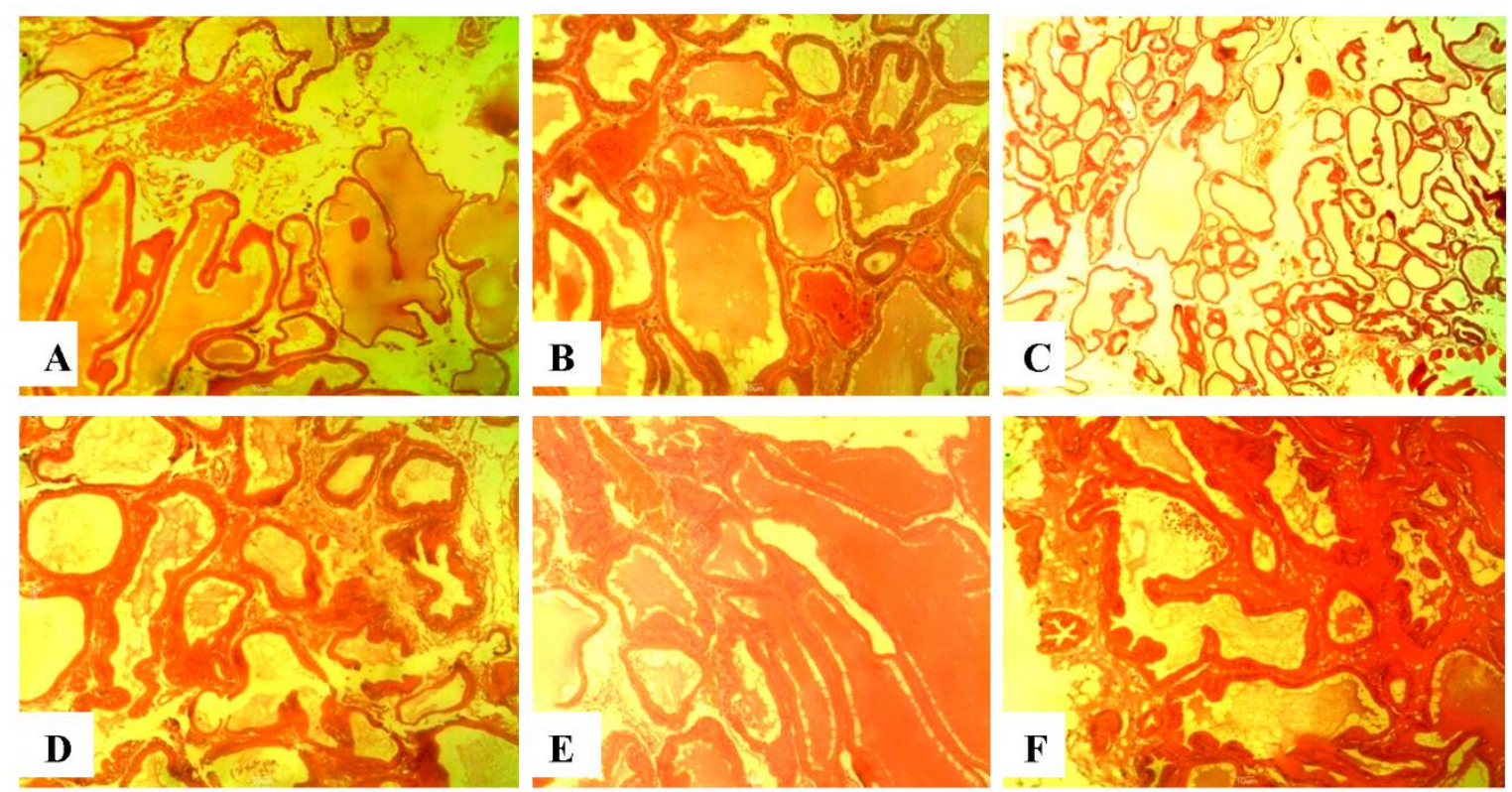

Figure 1. Photomicrograph of prostate tissue in the control rat showed normal histological appearances composed of normal convolutions, usually lined by two layer of epithelium with clear basal polarity of the nuclei (Plate A). At the same time the prostate tissue of albino rat in the untreated group showed severe multiple blood congestions observed in the fibromuscular stroma (Plate B). Further degeneration in the untreated group such as enlarged acini, mostly distended with secretory materials was observed. Moreover, prostate tissue exhibited back-to-back micro acini with improved intra acini papillary convolutions in the treatment groups (Plate $\mathbf{C}-\mathbf{F}$ ).

\section{Conclusions}

The administration of EECSL improved and restored serum prostatic epithelial cells, antioxidant, and lipid profile levels. It lowered the serum testosterone which had a direct influence on the DHT concentration. The safety of EECSL is assured, hence, may be considered effective in ameliorating benign prostatic hyperplasia. This study may serve as a scientific documentation by the traditional healers in the management of BPH in North Central of Nigeria. Further studies are required to establish the mechanism of action of EECSL which is major limitations of our work. Also, the extension of treatment days beyond fourteen days for a better potency of the extract.

\section{Funding:}

\section{References}

1. Aakula, A.; Kohonen, P.; Leivonen, S. Systematic identification of microRNAs. that impact on proliferation of prostate cancer cells and display changed expression in tumor tissue. Eur. Urol. 2016, 69, 1120-1128.

2. Abell, L.L.; Levey, B.B.; Brodie, B.B.; Kendall, F.E. Extraction of cholesterol. J. Biol. Chem. 1952, 195, 357-363.

3. Aebi, H.E. Catalase. In Methods of Enzymatic Analysis, 3rd ed.; Bergmeyer, H.U., et al., Eds.; Weinheim: Deerfield Beach, FL, USA, 1983; pp. 273-285. 
The 1st International Electronic Conference on Antioxidants in Health and Disease, 1-15 December 2020

4. Afriyie, D.K.; Asare, G.A.; Bugyei, K.; Adjei, S.; Lin, J.M.; Peng, J.; Hong, Z.F. Treatment of benign prostatic hyperplasia with Croton Membranaceus in an experimental animal model. J. Ethnopharmacol. 2014, 157, 9098.

5. Albers, J.J.; Warmick, G.R.; Cheng, M.C. Determination of high density lipoprotein (HDL)-cholesterol. Lipids 1978, 13, 926-932.

6. Aliyu, Z.; Yusha'u, M.; Aliyu, B.S. Anti malarial activity of Cassia sieberiana leaf extracts. Open Conf. Proc. J. 2013, 4, 72-76.

7. Al-Trad, B.; Aljabali, A.; Al Zoubi, M.; Shehab, M.; Omari, S. Effect of gold nanoparticles treatment on the testosterone-induced benign prostatic hyperplasia in rats. Int. J. Nanomed. 2019, 14, 3145-3154.

8. Aryal, M.; Pandeya, A.; Gautam, N.; Baral, N.; Lamsal, M. Oxidative stress in benign prostatic hyperplasia. Nepal. Med. Collj. 2007, 9, 222-224.

9. Aydin, A.; Arsova-Sarafinovska, Z.; Sayal, A.; Eken, A.; Erdem, O.; Erten, O.; Ozok, Y.; Dimovski, A. Oxidative stress and antioxidant status in non-metastatic prostate cancer and benign prostatic hyperplasia. Clin. Biochem. 2006, 39, 176-179.

10. Babson, A.L.; Greeley, S.J.; Coleman, C.M.; Philips, G.E. Phenolphthalein monophosphate as a substrate for serum alkaline phosphatase. Clin. Chem. 1966, 12, 482-490.

11. Bhavsar, A.; Verma, S. Anatomic imaging of the prostate. Biomed. Res. Int. 2014, 1-9.

12. Bullock, T.L.; Andriole, G.L. Emerging drug therapies for benign prostatic hyperplasia. Expert Opin. Emerg. Drugs 2006, 11, 111-123.

13. Donkor, K.; Okine, K.N.L.; Abotsi, M.K.W.; Woode, E. Anti-imflammatory and anti-nociceptive effects of ethyl acetate fraction of root back of Cassia sieberiana D. C. in Murine models. Pharmacologia 2013, 4, 301310.

14. Duru, R.C.; Njoku, O.U.; Maduka, I.C.; Ugonabo, M.C.; Ugwueme, F.O. Artherogenic lipid markers and testosterone levels in Nigerian men with prostate disorders. Asian Pac. J. Health Sci. 2015, 2, 48-255.

15. Drury, R.A.; Wallington, A.; Cameroun, S.R. Carleton's Histological Techniques; Oxford University Press: New York, NY, USA, 1967; pp. 1-420.

16. Duwiejua, M.; Panyin, A.B.; Weremfo, A.; Woode, E.; Ansah, C. Antinociceptive activity of the ethanolic extract of the root bark of Cassia sieberiana (Fam. Caesalpinaceae). J. Pharm. Biores 2007, 4, 49-58.

17. Ejike, C.E.C.C.; Ezeanyika, L.U.S. Management of experimental benign prostatic hyperplasia in rats using a feedbased therapy containing Telfairia occidentalis seeds. Afr J. Tradit. Complement. Altern. Med. 2011, 8 , 398-404.

18. Fridovich, I. Superoxide dismutase: An adaptation to a pragmatic gas. J. Biol. Chem. 1989, 264, 7762-7764.

19. Friedewald, W.T.; Levy, R.I.; Fredricson, D.S. Estimation of low-density lipoprotein cholesterol in plasma, without use of the preparative ultracentrifuge. J. Clin. Chem. 1972, 18, 499-502.

20. Goldberg, D.M.; Spooner, R.J. Methods of Enzymatic Analysis, 3rd ed.; Bergmeyen, H.V., Ed.; 1983; Volume 3, pp. 258-265.

21. Ikeyi, A.P.; Okagu, I.U.; Ezeanyika, L.U.S.; Alumanah, E.O. Zapotecaportoricensis root crude methanol extract and its fractions normalizes aberrations associated with benign prostatic hyperplasia in rats. All Life 2020, 13, 360-372.

22. Indian Council of Medical Research. Guidelines for The Use of Laboratory Animals in Medical Colleges. Indian Council of Medical Research: New Delhi, Indian, 2001; pp. 3-13.

23. Liao, C.H.; Li, H.Y.; Chung, S.D.; Chiang, H.S.; Yu, H.J. Significant association between serum dihydrotestosterone level and prostate volume among Taiwanese men aged 40-79 years. Aging Male 2012, 15, 28-33.

24. Liu, Y.; Zuckier, L.S.; Ghesani, N.V. Dominant uptake of fatty acid over glucose by prostate cells: A potential new diagnostic and therapeutic approach. Anticancer Res. 2010, 30, 369-374.

25. Mbaka, G.; Anunobi, C.; Ogunsina, S.; Osiagwu, D. Histomorphological changes in induced benign prostatic hyperplasia with exogenous testosterone and estradiol in adult male rats treated with aqueous ethanol extract of Secamone afzelii. Egypt J. Basic Appl. Sci. 2017, 4, 15-21.

26. Mimae, R. Liver enzymes as an indicator of hepatic insult. J. Healthcare Hyg. 2017, 1, 1-4.

27. Mustafa, M.; Salih, A.F.; Illzam, E.M.; Sharifa, A.M.; Suleiman, M.; Hussain SS. Prostate Cancer: Pathophysiology, diagnosis, and prognosis. IOSR J. Dent. Med. Sci. 2016, 15:4-11. 
The 1st International Electronic Conference on Antioxidants in Health and Disease, 1-15 December 2020

28. Olapade, A.A.; Akinoso, R.; Oduwaye, A.O. Changes in some physicochemical properties of Cassia sieberiana seed during roasting. Niger. Food J. 2012, 30 26-34.

29. Park, K.H.; Kim, K.S.; Lee, W.S.; Chung, J.; Lee, B.; Na, W.S.; Park, G.C.; Kim, O.Y. A herbal formula, comprising Panax ginseng and bee-pollen, inhibits development of testosteroneinduced benign prostatic hyperplasia in male Wistar rats. Saudi J. Biol. Sci. 2017, 24, 1555-1561.

30. Parsons, J.K.; Bergstrom, J.; Barrett-Connor, E. Lipids, lipoproteins and the risk of benign prostatic hyperplasia in community-dwelling men. BJU Int. 2008, 101, 313-318.

31. Rafieian-Kopaei, M. Medicinal plants and the human needs. J. Herbmed. Pharmacol. 2012, 1, 1-2.

32. Reitman, S.; Frankel, S. A colorimetric method for the determination of serum glutamic oxaloacetic and glutamic pyruvic transaminases. Am. J. Clin. Pathol. 1957, 28, 56-63.

33. Roehrborn, C.G.; Nuckolls, J.G.; Wei, J.T.; Steers, W.B.P.H. Registry and Patient Survey Steering Committee. The benign prostatic hyperplasia registry and patient survey: Study design, methods and patient baseline characteristics. BJU Int. 2007, 100, 813-819.

34. Sam, G.H.; Mensah, M.L.K.; Nyakoa-Ofori, N. Pharmacognostic Studies and Standardization of Cassia sieberiana Roots. Pharmacogn. J. 2011, 4, 12-17.

35. Singh, D. Leaf phenology of Cassia sieberiana L. in Ksusta campus of Kebbi State, Nigeria. Sci. Technol. Public Policy 2017, 1, 23-28.

36. Singh, R. Medicinal plants: A review. J. Plant. Sci. 2015, 3, 50-55.

37. Sliva, O.; Ferreira, E.; Vaz-pato M.; Gome, E. Guinea Bissau's plant Vitro susceptibility studies on Neisseria gonorrhoeae. Int. J. Pharm. 1997, 35, 323-328.

38. Sy, G.Y.; Fall, A.D.; Diatta, W.; Gueye, M.; Badji, K.; Bassène, E.; Faye, B. Analgesic and anti-inflammatory activity of aqueous root extract of Cassia sieberiana DC (Caesalpiniaceae). Afr J. Pharm. Pharmacol. 2009, 3 651-653.

39. Thu, H.E.; Mohamed, I.N.; Hussain, Z.; Jayusman, P.A.; Shuid, A.N. Eurycoma longifolia as a potential adoptogen of male sexual health: A systematic review on clinical studies. Chin. J. Nat. Med. 2017, 15, 71-80.

40. Tietz, N.W. Clinical Guide to Laboratory Tests (ELISA), 2rd ed.; Saunders, W.B., Ed.; Company, Philadelphia, 1990; pp. 932-933.

41. Veeresh, B.S.V.; Veeresh, B.; Patill, A.A.; Warke, Y.B. Lauric acid and myristic acid prevent testosterone induced prostatic hyperplasia in rats. Eur. J. Pharmacol. 2010, 625, 262-265.

42. Velonas, V.M.; Woo, H.H.; Remedios, C.G.; Assinder, S.J. Current status of biomarkers for prostate cancer. Int. J. Mol. Sci. 2013, 14, 11034-11060.

43. Wallin, B.; Kosengreen, B.; Shertzer, H.G.; Camejo, G. Lipoprotein oxidation and measurement of TBARS formation in a single microtitre plants; its use for evaluation of antioxidants. Anal. Biochem. 1993, 208, 1015.

44. Yano, M.; Yasuda, K.; Kitahara, S.; Nakajima, C.; Iimura, Y.; Yamanishi, T. The reason why prostatic hyperplasia causes lower urinary track symptoms. Asian Med. J. 2001, 44, 91-96.

(C) 2020 by the authors; licensee MDPI, Basel, Switzerland. This article is an open access article distributed under the terms and conditions of the Creative Commons by Attribution (CC-BY) license (http://creativecommons.org/licenses/by/4.0/). 